\title{
Factors Determining the Choice of Health Care of Textile and Engineering Industrial Workers in Coimbatore
}

\author{
N. Savitha \\ Assistant Professor, School of Social Sciences and Languages, VIT University, \\ Vellore
}

\begin{abstract}
Industrial workers constitute only a segment of general population and the factors that influence the health of the population also apply equally to industrial workers. The present study would bring out the availability and adequacy of health facilities in the urban Coimbatore. Therefore, the study of the people's perception of health care services would indicate the line of improvement to be made in the health care services in future. Coimbatore is one of the most industrially developed Districts in Tamil Nadu and has the pride of being called the "Manchester of South India". The data collected from both the textile and engineering industries in Coimbatore city was 1447 employees. It is found that workers who have been born and brought up in urban areas have shown higher tendency to avail private health care services $(81 \%)$ than those workers whose nativity status is rural areas. Obviously, the reverse pattern is noticed among the sample workers in the case of government health services. The chi-square results between the nativity status and workers' choice of health care services is found to be highly significant $(p<0.001)$. It is interesting to note that when it comes to health, patients are psychologically ready to pay any amount. They never tend to be treated in low cost hospitals but prefer hospitals where good treatment and quality services are available. The findings show that the quality of health care services playing a vital role in choosing the type of health facilities by the workers.
\end{abstract}

Key words: Health status, Healthcare choice, Textile and Engineering workers

\section{INTRODUCTION}

A number of health problems require intensive medical treatment and personal care, which normally are not available in a patient's home or in the clinic of a doctor. This is possible only in a hospital where a large number of professionals and technically qualified people apply their knowledge and skill with the help of advanced sophisticated equipment and appliances. Multifaceted developments in the society have made the people more conscious of their rights. Today, the customers of health services demand the most modern and the best possible means of medical care and attention. They want everything within the four walls of the hospital, which has made the hospital a complex organization. With increasing awareness among the customers about their rights, the patients, as customers of health services, expect quality healthcare.

A number of research studies address the question of how customers select health services. Research findings that provide insight into how customers select hospitals and physicians provide important input to healthcare providers who use this information to attract patients and to improve the services they render. Patients are better informed and they know more about healthcare services. They want to be involved in the medical care process. For this reason they make their own decisions. They shop 
for and select the best hospital. They choose their doctor or change him or her if they are not satisfied. Some of the customers have a positive and favourable opinion about a hospital; some may have a prejudice against it while some others may carry a neutral attitude about the hospital. Significantly, a large number of customers are regularly lost to the newly opened corporate hospitals and private clinics. The customers desire to try the newness of the alternatives because some of them had a better location, offered wide range of services and had newer infrastructure in place. In the present chapter, an attempt is made to examine the choice and preference of health care services of industrial workers. Concentrating on the factors that the workers consider important in the selection of health care services, the study covers several other aspects also.

\section{REVIEW OF EARLIER STUDIES}

Various studies relating to the choice of health care services and health insurance have been conducted by different social scientists at micro as well as macro level in India and abroad. While there has been much literature available about the health care services, it is found in the study that the choice of health care services and enrolment of health insurance among industrial workers is of recent development. An attempt has been made in the study to review the earlier studies relating to the health care choice and the enrolment of health insurance among industrial workers. Madhu Nagla (1989) (1991) the educated patients with urban background and high income were better aware of illness and recognized them were correctly and were also, more favourably, disposed towards seeking medical care. Flex Moncler and Murugesan (1990) in their study on rural health care service had identified the problems faced by the consumers in availing of health care services offered by the Government health services. An attempt has also been made to study the relationship between the income level of the respondents and the sources of health care service. Venkateswara Rao (1991) Barrier of distance between villages and the city hospitals also prevents them from seeking specialized medical treatment. Ramanan Sunder (1992) the disparity between the rich and the poor in their dependence on private vs. public health care facilities.

Valdivia (2002), analyses the magnitude and nature of socio - economic differences in the utilisation of outpatient health care services in Peru. To estimating a Probit model with random effects at the district level to control for the systematic geographic bias associated with the optimal public allocation of such infrastructure, the income effect is found to be very large, even after controlling for other socio-economic characteristics.

According to Jawahar and Kanagaraj (2006), education had significant positive effect on the choice of public health care and negative effect on the choice of private health care. As the number of episodes increase there seems to be a shift from private health care provider to public health care provider.

Canaviri (2007) in his study modeled out a health care provider choice in Bolivia with a Random Parameter Logit using MECOVI (Continuous Household Survey) during the period 1999 and 2000. It was found that price and income were important determinants of the decision choice of health care provider. The perception of Quality was significant just for private health facilities expect for children group. People would prefer private to Government when they fall ill.

Yingchun Peng and et al. (2010) their study was designed to assess the factors associated with healthseeking behaviour and to explore feasible solutions to the obstacles migrant workers in China faced with when accessing health-care. The multilevel methodology (MLM) was used to demonstrate the independent effects of the explanatory variables on health seeking behaviour in migrant workers. The multilevel model analysis indicates that health-seeking behaviour among migrants is significantly associated with their insurance coverage. Meanwhile, such factors as household monthly income per capita and working hours per day also affect the medical visitation rate of the migrant workers in Beijing.

Rahman and et al. (2011) Knowledge about the existing disease pattern and health seeking behaviour is essential to provide need based health care delivery to any population and to make the health care 
system more pro-poor. Their study concluded that it is important to develop a need based health care delivery system and actions should be taken to improve the overall scenario of health system of rural Bangladesh.

\section{THE IDENTIFICATION OF RESEARCH PROBLEM}

People constitute the valuable human resources needed for the development of any country. It is needless to say that the development of the national economy rests on the health, ability and wellbeing of the people. The promotion and protection of health of the people is essential for sustained economic and social development. In fact, health is an important input in any process of development. In assessing a country's resources for economic development, the health of the people should be reckoned with. In a country like India, the problem of health is an enormous one, where the majority of poor is outside the effective medical network. The government hospitals have not failed to equip poor to become customers in basic medical services nor have they provided them free effective medical services. In the Indian environment, where majority of the government hospitals are found in a deplorable condition, it is need of the hour that charitable trusts, voluntary agencies, private hospitals and corporate sector come ahead and carry forward the task of making available to the society the best possible health services.

The health status of urban population is peculiar in character as majority of them are floating population and the awareness of urban industrial workers about various health problems like curative, maternal and child health differ widely due to differences in their socio-economic set up. The vulnerable sections in the urban areas are suffering from morbidity problems especially diseases of poverty and are not having enough access to health care services. Due to the low income, they provide first priority to food and later only for treatment. Since income being low, they first usually approach the public hospitals, but the poor and inadequate services rendered by them compelled to go for private health functionaries competent enough to handle the user's problem is also crucial. Laboratory facilities and supply of drugs needed for diagnosis and treatment often play a vital role in determining access to health care services. Access to health care systems is deeply conditioned by one's possession and income (World Bank, 1998). Financial barrier is still a dominant problem for access to necessary healthcare for majority of the Indians.

If India continues on its present path, the mismatch between its health system and its health problems will became only more severe. The present moment is a decisive one because the government of India is now seeking to define a better health system for the country, one that can take better advantage of the capacity of the private sector and deliver better service and outcomes for all regions and socioeconomic groups. Over the years, though the researchers, academicians and governments have tried to find ways and means to this, many issues and aspects of health, viz. provision of quality services and an effective delivery system, managing health expenditure and its financing and adequate expansion of service network to rural and tribal areas to achieve equity in access to health care are yet to be completely resolved.

The above stated problems have direct impact on the workers of textile and foundry (engineering) sectors. Hence, an attempt is made in this study to bring to light the actual problems faced by these workers in availing the health care services either from government or private hospitals. The availability of both Government and private hospitals in the delivery of health care services vis-a-vis the perception of the target population of these services can be effectively evaluated on the basis of the result of the study. Therefore, the present study was mainly focused for the choice of health care services among industrial workers.

\section{RESEARCH METHODOLOGY}

Coimbatore is one of the most industrially developed cities in Tamil Nadu and has the pride of being called the "Manchester of South India". Coimbatore is the third largest city in Tamil Nadu state in 
India; it has more than 40,000 small, medium and large-scale industries, which serve the engineering needs of the major parts of the country. The decision to select foundry and textile industries is due to the fact that the industrial activity in Coimbatore region depends more on these units and the workers of these units are prone to health hazards due to pollution. Due to the nature of selected issue and outcomes a "convenient sampling method" was adopted and a total of 1447 respondents were selected for the final study. To test the pre-defined null hypothesis, the study has also adopted a logistic regression model to determine the factors determining the probability of Choice of Health care Services among the selected industrial workers.

\section{THEORETICAL BACKGROUND OF THE LOGISTIC REGRESSION MODEL (LRM)}

The study considers outcome factor of choice of healthcare services which holds a dichotomous properties and most of the independent factors holds quantitative properties. Therefore, it would be more appropriate to use a qualitative model rather than OLS procedures. Hence, the study has applied a binary logit model to examine the issues.

$$
\begin{aligned}
& \text { Model } \\
& \qquad \begin{aligned}
Y_{i}=\left[P_{i} / 1-P_{i}\right]= & \beta_{0}+\beta_{1} \operatorname{Gen}_{i}+\beta_{2} \text { Age }_{i}+\beta_{3} \text { Nat }_{i}+\beta_{4} \operatorname{Com}_{i}+\beta_{5} E d u_{i}+\beta_{6} \text { MFI }_{i}+\beta_{7} C T_{i}+\beta_{8} \text { WTHF }_{i}+\beta_{9} \text { Qlty Serv }_{i} \\
& +\beta_{10} \text { GHFNH }_{i}+\beta_{11} F D_{i}+u_{i}
\end{aligned}
\end{aligned}
$$

Where,

$\beta_{0}$ to $\beta_{1}$ - Parameters of estimates

$\beta_{1}$ - Gender - '0' for Male and '1' for Female

$\beta_{2}$ - age - Current age

$\beta_{3}$ - Nativity - '0' for Rural and '1' for Urban

$\beta_{4}$ - Community

$\beta_{5}$ - Educational Status

$\beta_{6}$ - Monthly Family Income

$\beta_{7}$ - Consultation Time

$\beta_{8}$ - Waiting time at Health Facility

$\beta_{9}-$ Quality of Services

$\beta_{10}$ - Government Health Facility nearer to Household

$\beta_{11}$ - Have a Family Doctor

$\mathrm{u}_{\mathrm{i}}$ - Error term

\section{DIFFERENTIALS IN THE WORKERS' CHOICE OF HEALTH CARE SERVICES}

In this section, an attempt is made to analyse the differentials, if any, exist in workers' choice of health care services across their selected background characteristics. The analysis is carried out with the help of cross-tabulations and chi-square test of significance keeping the choice of health care services as dependent variable, viz., from government health facilities and private health centres.

It is evident that the percentage of workers who have availed health care services from private health centres is much higher irrespective their gender background, but such present is just one percentage point is higher among males as compared to females, whereas such pattern is reversed in the case of government health facilities.

When the differentials in the choice of health care services examined across their age, it is observed that the percentage of visiting private health facilities is appear to be higher among those belonged to 
higher age groups (79\% and $77 \%$, respectively among those whose age is 45 years $\&$ above and $30-$ 44 years) than those who are younger in age (15-29 years).

Table 1: Gender, Age, Marital Status and Nativity Status of the Sample Respondents By their Choice of Health Care Services

\begin{tabular}{|c|c|c|c|c|}
\hline \multirow{2}{*}{\multicolumn{2}{|c|}{$\begin{array}{l}\text { Gender / Age / Marital Status / Nativity } \\
\text { Status of the Respondents }\end{array}$}} & \multicolumn{3}{|c|}{ Choice of Health Care Services } \\
\hline & & \multirow{2}{*}{$\begin{array}{l}\text { Government } \\
200 \\
(23.2) \\
\end{array}$} & \multirow{2}{*}{$\begin{array}{l}\text { Private } \\
662 \\
(76.8) \\
\end{array}$} & \multirow{2}{*}{$\begin{array}{l}\text { Total } \\
862 \\
(100.0) \\
\end{array}$} \\
\hline Ondor & Male & & & \\
\hline Gencier & Female & $\begin{array}{l}144 \\
(24.6)\end{array}$ & $\begin{array}{l}441 \\
(75.4)\end{array}$ & $\begin{array}{l}585 \\
(100.0)\end{array}$ \\
\hline \multirow{3}{*}{ Age } & $15-29$ & $\begin{array}{l}154 \\
(26.1)\end{array}$ & $\begin{array}{l}435 \\
(73.9)\end{array}$ & $\begin{array}{l}589 \\
(100.0)\end{array}$ \\
\hline & $30-44$ & $\begin{array}{l}127 \\
(22.7)\end{array}$ & $\begin{array}{l}433 \\
(77.3)\end{array}$ & $\begin{array}{l}560 \\
(100.0)\end{array}$ \\
\hline & $45+$ & $\begin{array}{l}63 \\
(21.1)\end{array}$ & $\begin{array}{l}235 \\
(78.9)\end{array}$ & $\begin{array}{l}298 \\
(100.0)\end{array}$ \\
\hline \multirow{2}{*}{ Marital Status } & $\begin{array}{l}\text { Never Married / } \\
\text { Widowed / Divorced }\end{array}$ & $\begin{array}{l}118 \\
(25.8)\end{array}$ & $\begin{array}{l}340 \\
(74.2)\end{array}$ & $\begin{array}{l}458 \\
(100.0)\end{array}$ \\
\hline & Currently Married & $\begin{array}{l}226 \\
(22.9)\end{array}$ & $\begin{array}{l}763 \\
(77.1)\end{array}$ & $\begin{array}{l}989 \\
(100.0)\end{array}$ \\
\hline \multirow{2}{*}{ Nativity Status } & Rural & $\begin{array}{l}247 \\
(26.2)\end{array}$ & $\begin{array}{l}695 \\
(73.8)\end{array}$ & $\begin{array}{l}942 \\
(100.0)\end{array}$ \\
\hline & Urban & $\begin{array}{l}97 \\
(19.2)\end{array}$ & $\begin{array}{l}408 \\
(80.8)\end{array}$ & $\begin{array}{l}505 \\
(100.0)\end{array}$ \\
\hline \multicolumn{2}{|c|}{$x^{2}$-Value; Sig. Level } & \multicolumn{3}{|c|}{$8.922 ; P<0.001$} \\
\hline \multicolumn{2}{|l|}{ Total } & $\begin{array}{l}334 \\
(23.8)\end{array}$ & $\begin{array}{l}1103 \\
(76.2)\end{array}$ & $\begin{array}{l}1447 \\
(100.0)\end{array}$ \\
\hline
\end{tabular}

Source: Primary Data

Bi-variety analysis in the case of choice of health care services by workers' marital status reveal that the percentage of those availing health care services from private health facilities is marginally higher among those who are currently married as against to those who are in other type of marital status. The chi-square results in all the case of all these three factors did not turn out as statistically significant. It is obvious to note that workers who born and brought up in urban areas have shown higher tendency to avail private health care services $(81 \%)$ than those workers whose nativity status is rural areas. Obviously, the reverse pattern is noticed among the sample workers in the case of government health services. Further, it is also interesting to note that the chi-square results between the nativity status and workers' choice of health care services is found to be highly significant $(p<0.001)$.

Information provided in the above table 2 reveal that the percentage of workers who visited private health centres for medical and health services is conspicuously higher among those who belonged to backward \& forward communities ( $89 \%$ ) as well as most backward communities (87\%) than those from scheduled castes / tribes (45\%). The reverse pattern is noticed in the case of those who availed such services from government health facilities. The chi-square results between the community background of the sample workers and their choice of health care services are turn out as highly significant $(p<0.001)$. 
Table 2: Community, Educational Status and Monthly Income of the Sample Respondents by their Choice of Health Care Services

\begin{tabular}{|c|c|c|c|c|}
\hline \multirow{2}{*}{\multicolumn{2}{|c|}{$\begin{array}{l}\text { Community / Educational Status } / \\
\text { Monthly Income of the } \\
\text { Respondents }\end{array}$}} & \multicolumn{3}{|c|}{ Choice of Health Care Services } \\
\hline & & \multirow{2}{*}{$\begin{array}{l}\text { Government } \\
218 \\
(55.1)\end{array}$} & \multirow{2}{*}{\begin{tabular}{|l|} 
Private \\
178 \\
$(44.9)$
\end{tabular}} & \multirow{2}{*}{$\begin{array}{l}\text { Total } \\
396 \\
(100.0)\end{array}$} \\
\hline \multirow{3}{*}{ Community } & $\mathrm{SC} / \mathrm{ST}$ & & & \\
\hline & MBC & $\begin{array}{l}64 \\
(13.3)\end{array}$ & $\begin{array}{l}418 \\
(86.7)\end{array}$ & $\begin{array}{l}482 \\
(100.0)\end{array}$ \\
\hline & $\mathrm{BC} / \mathrm{FC}$ & $\begin{array}{l}62 \\
(10.9)\end{array}$ & $\begin{array}{l}507 \\
(89.1)\end{array}$ & $\begin{array}{l}569 \\
(100.0)\end{array}$ \\
\hline \multicolumn{2}{|c|}{$x^{2}$-Value; Sig. Level } & \multicolumn{3}{|c|}{$295.137 ; p<0.001$} \\
\hline \multirow{4}{*}{$\begin{array}{l}\text { Educational } \\
\text { Status }\end{array}$} & Illiterate & $\begin{array}{l}30 \\
(30.9)\end{array}$ & $\begin{array}{l}67 \\
(69.1)\end{array}$ & $\begin{array}{l}97 \\
(100.0)\end{array}$ \\
\hline & Primary Education & $\begin{array}{l}141 \\
(20.8)\end{array}$ & $\begin{array}{l}537 \\
(79.2)\end{array}$ & $\begin{array}{l}678 \\
(100.0)\end{array}$ \\
\hline & Secondary Education & $\begin{array}{l}119 \\
(26.5)\end{array}$ & $\begin{array}{l}330 \\
(73.5)\end{array}$ & $\begin{array}{l}449 \\
(100.0)\end{array}$ \\
\hline & $\begin{array}{l}\text { Higher Secondary and } \\
\text { above Education }\end{array}$ & $\begin{array}{l}54 \\
(24.2)\end{array}$ & $\begin{array}{l}169 \\
(75.8)\end{array}$ & $\begin{array}{l}223 \\
(100.0)\end{array}$ \\
\hline \multicolumn{2}{|c|}{$x^{2}-$ Value; Sig. Level } & \multicolumn{3}{|c|}{$7.926 ; p<0.05$} \\
\hline \multirow{3}{*}{$\begin{array}{l}\text { Monthly } \\
\text { Income } \\
\text { (in Rs.) }\end{array}$} & Below 3000 & $\begin{array}{l}69 \\
(31.1)\end{array}$ & $\begin{array}{l}153 \\
(68.9)\end{array}$ & $\begin{array}{l}222 \\
(100.0)\end{array}$ \\
\hline & $3000-6000$ & $\begin{array}{l}237 \\
(21.8)\end{array}$ & $\begin{array}{l}848 \\
(78.2)\end{array}$ & $\begin{array}{l}1085 \\
(100.0)\end{array}$ \\
\hline & Above 6000 & $\begin{array}{l}38 \\
(27.1)\end{array}$ & $\begin{array}{l}102 \\
(72.9)\end{array}$ & $\begin{array}{l}140 \\
(100.0)\end{array}$ \\
\hline \multicolumn{2}{|c|}{$x^{2}$-Value; Sig. Level } & \multicolumn{3}{|c|}{$9.650 ; p<0.01$} \\
\hline \multicolumn{2}{|l|}{ Total } & $\begin{array}{l}344 \\
(23.8)\end{array}$ & $\begin{array}{l}1103 \\
(76.2)\end{array}$ & $\begin{array}{l}1447 \\
(100.0)\end{array}$ \\
\hline
\end{tabular}

Source: Primary Data

The table shows that the percentage of workers who have gone to private health clinics / hospitals is as high as 79 per cent among those who have completed primary education closely followed by higher education (76\%) and secondary education (73.5\%), whereas such percent is about 69 among the illiterate workers. Obviously, the percent of workers who availed the health services from government facilities is higher among the illiterates as compared to those who have different levels of education. The chi-square results too supported such pattern of association between the level of educational status of the respondents and type of health care services utilised to a moderate level of significance $(p<0.05)$. Table 2 highlights that the percentage of workers who availed health care services is much higher among those who earn a monthly income of Rs. 3000-6000 closely followed by those who earn 
above Rs. 6000, whereas such per cent is about 69 in the case of workers who earn comparatively less income per month (Rs. 300 or less). The reverse pattern is quite evident in the case of availing such services from government health facilities. Here too, the chi-square results between the monthly income of the workers and their choice of health care services are turn out as highly significant $(p<0.01)$. All these data support the fact that on the whole workers who are better in their socioeconomic status are making use of private health facilities to a large extent as against to those who belong to lower socio-economic status.

Table 3: Availability of Government Health Facility nearer to Household and Sample Respondents have a Family Doctor for their Health Care Services

\begin{tabular}{|c|c|c|c|c|}
\hline \multirow{2}{*}{\multicolumn{2}{|c|}{$\begin{array}{l}\text { Availability of Government Health } \\
\text { Facility nearer to Household and } \\
\text { Sample Respondents have a } \\
\text { Family Doctor }\end{array}$}} & \multicolumn{3}{|c|}{ Choice of Health Care Services } \\
\hline & & Government & Private & Total \\
\hline \multirow{4}{*}{$\begin{array}{l}\text { Quality of Health Care } \\
\text { Services }\end{array}$} & Poor & $\begin{array}{l}59 \\
(43.1)\end{array}$ & $\begin{array}{l}78 \\
(56.9)\end{array}$ & $\begin{array}{l}137 \\
(100.0)\end{array}$ \\
\hline & Average & $\begin{array}{l}115 \\
(33.4)\end{array}$ & $\begin{array}{l}229 \\
(66.6)\end{array}$ & $\begin{array}{l}344 \\
(100.0)\end{array}$ \\
\hline & Good & $\begin{array}{l}134 \\
(22.3)\end{array}$ & $\begin{array}{l}467 \\
(77.7)\end{array}$ & $\begin{array}{l}601 \\
(100.0)\end{array}$ \\
\hline & Excellent & $\begin{array}{l}36 \\
(9.9)\end{array}$ & $\begin{array}{l}329 \\
(90.1)\end{array}$ & $\begin{array}{l}365 \\
(100.0)\end{array}$ \\
\hline \multicolumn{2}{|l|}{$x^{2}-$ Value; Sig. Level } & \multicolumn{3}{|c|}{$85.528 ; p<0.001$} \\
\hline \multirow{2}{*}{$\begin{array}{l}\text { Availability } \\
\text { Government Health } \\
\text { Facility nearer to } \\
\text { Household }\end{array}$} & No & $\begin{array}{l}183 \\
(20.9)\end{array}$ & $\begin{array}{l}691 \\
(79.1)\end{array}$ & $\begin{array}{l}874 \\
(100.0)\end{array}$ \\
\hline & Yes & $\begin{array}{l}161 \\
(28.1)\end{array}$ & $\begin{array}{l}412 \\
(71.9)\end{array}$ & $\begin{array}{l}573 \\
(100.0)\end{array}$ \\
\hline \multicolumn{2}{|l|}{$x^{2}-$ Value; Sig. Level } & \multicolumn{3}{|c|}{$9.790 ; p<0.001$} \\
\hline \multirow{2}{*}{ Have a Family Doctor } & No & $\begin{array}{l}252 \\
(22.2)\end{array}$ & $\begin{array}{l}883 \\
(77.8)\end{array}$ & $\begin{array}{l}1135 \\
(100.0)\end{array}$ \\
\hline & Yes & $\begin{array}{l}92 \\
(29.5)\end{array}$ & $\begin{array}{l}220 \\
(70.5)\end{array}$ & $\begin{array}{l}312 \\
(100.0)\end{array}$ \\
\hline \multicolumn{2}{|l|}{$x^{2}-$ Value; Sig. Level } & \multicolumn{3}{|c|}{ 7.166; $p<0.001$} \\
\hline \multicolumn{2}{|l|}{ Total } & $\begin{array}{l}344 \\
(23.8)\end{array}$ & $\begin{array}{l}1103 \\
(76.2)\end{array}$ & $\begin{array}{l}1447 \\
(100.0)\end{array}$ \\
\hline
\end{tabular}

Source: Primary Data

From table 3 it is clear that quality of health care services is playing a vital role in choosing the type of health facilities by the workers. For instance, the percentage of the workers who utilised the private health care services is relatively lower (57\%) when they perceive and receive 'poor' health care services, which has increased consistently to 66.6 per cent, 77.7 per cent and then to as high as 90 per cent with an increase in the level of quality of services received at the health centres to the extent of 'average', 'good' and 'excellent', respectively. Conversely, the percentage of workers visiting government health facilities has decreased with an increase in the level of quality of health care 
services. Apparently, the chi-square results in this regard has turned out as highly significant indicating that there exists a strong association between the quality of health services and the choice of health care services $(p<0.001)$. The percentage of workers availing health care services from private institutions is fairly higher (79\%) when do not have a government health centre nearer to their household as compared to those who do not have $(72 \%)$, whereas the reverse pattern is noticed in the case of workers who are opting for government health facilities. The chi-square results too in this regard turn out as highly significant $(p<0.001)$. The percentage of workers who visited private health care facilities is reasonably higher when they do not have a family doctor as against to those who have $(78 \%$ and $70.5 \%$, respectively), whereas the opposite pattern is noticed in the case of workers who availed health care services from government facilities. Such pattern is possible because of the reason that the workers who have a family doctor is much less and also there is possibility that all the members of the family may not go to the same doctor since the type of illnesses vary among them.

\section{RESULTS AND DISCUSSIONS}

Table 4: Logistic Regression Results on Respondents' Choice of Health Care Facilities

\begin{tabular}{|c|c|c|c|}
\hline Explanatory Variables & Beta & $\begin{array}{l}\text { Odds } \\
\text { Ratio }\end{array}$ & $\begin{array}{l}\text { Level } \\
\text { of Sig. }\end{array}$ \\
\hline $\begin{array}{l}\text { Gender (Ref: Males) } \\
\text { Females }\end{array}$ & $\begin{array}{l}- \\
-0.101\end{array}$ & $\begin{array}{l}1.000 \\
0.904\end{array}$ & $\begin{array}{l}-- \\
0.550\end{array}$ \\
\hline $\begin{array}{l}\text { Current Age (Ref: } 15-29 \text { Years) } \\
30-44 \text { Years } \\
45+\text { Years }\end{array}$ & $\begin{array}{l}-- \\
0.056 \\
0.204\end{array}$ & $\begin{array}{l}1.000 \\
1.057 \\
1.227\end{array}$ & $\begin{array}{l}-- \\
0.776 \\
0.416\end{array}$ \\
\hline $\begin{array}{l}\text { Nativity Status (Ref: Rural) } \\
\text { Urban }\end{array}$ & 0.269 & $\begin{array}{l}1.000 \\
1.308\end{array}$ & --133 \\
\hline $\begin{array}{l}\text { Community (Ref: SCs/STs) } \\
\text { Most Backward Castes } \\
\text { Backward \& Forward Castes }\end{array}$ & $\begin{array}{l}-- \\
2.413 \\
2.437\end{array}$ & $\begin{array}{l}1.000 \\
8.523 \\
11.435\end{array}$ & $\begin{array}{l}-- \\
0.001 \\
0.001\end{array}$ \\
\hline $\begin{array}{l}\text { Educational Status (Ref: Illiterate) } \\
\text { Primary School } \\
\text { Secondary School } \\
\text { Higher Secondary School and above }\end{array}$ & $\begin{array}{l}- \\
0.664 \\
0.527 \\
0.550\end{array}$ & $\begin{array}{c}1.000 \\
1.942 \\
1.694 \\
1.733\end{array}$ & $\begin{array}{l}-- \\
0.05 \\
0.121 \\
0.139\end{array}$ \\
\hline $\begin{array}{l}\text { Monthly Family Income (in Rs.) } \\
\text { (Ref: } 3000 \text { or less) } \\
3001-6000 \\
6001+\end{array}$ & $\begin{array}{l}-- \\
0.307 \\
-0.078\end{array}$ & $\begin{array}{l}1.000 \\
1.359 \\
0.925\end{array}$ & $\begin{array}{r}-- \\
0.01 \\
0.802\end{array}$ \\
\hline $\begin{array}{l}\text { Consultation Time (in minutes) (Ref: } 5 \text { ) } \\
10 \\
15 \\
20+\end{array}$ & $\begin{array}{l}-- \\
0.585 \\
1.073 \\
0.459 \\
\end{array}$ & $\begin{array}{l}1.000 \\
1.796 \\
2.998 \\
1.583 \\
\end{array}$ & $\begin{array}{l}- \\
0.01 \\
0.001 \\
0.111 \\
\end{array}$ \\
\hline $\begin{array}{l}\text { Waiting Time at Health Facility } \\
\text { (in minutes) (Ref: } 30 \text { or less) } \\
31-60 \\
61-90 \\
91+\end{array}$ & $\begin{array}{l}-- \\
-1.763 \\
-2.620 \\
-2.206\end{array}$ & $\begin{array}{l}1.000 \\
0.171 \\
0.073 \\
0.110\end{array}$ & $\begin{array}{l}-- \\
0.001 \\
0.001 \\
0.001\end{array}$ \\
\hline $\begin{array}{l}\text { Quality of Services (Ref: Poor) } \\
\text { Average } \\
\text { Good } \\
\text { Excellent }\end{array}$ & $\begin{array}{l}-- \\
0.311 \\
1.073 \\
2.203\end{array}$ & $\begin{array}{l}1.000 \\
1.364 \\
2.924 \\
9.049\end{array}$ & $\begin{array}{l}-- \\
0.229 \\
\mathbf{0 . 0 0 1} \\
\mathbf{0 . 0 0 1}\end{array}$ \\
\hline $\begin{array}{l}\text { Government Health Facility nearer to } \\
\text { Household (Ref: No) } \\
\text { Yes }\end{array}$ & --0.688 & $\begin{array}{l}1.000 \\
0.503\end{array}$ & 0.001 \\
\hline $\begin{array}{l}\text { Have a Family Doctor (Ref: No) } \\
\text { Yes }\end{array}$ & $--\overline{-0.628}$ & $\begin{array}{l}1.000 \\
0.533\end{array}$ & $\begin{array}{l}-- \\
0.001\end{array}$ \\
\hline $\begin{array}{l}-2 \text { Log likelihood } \\
\text { Chi-square (df) } \\
\text { Significance Level } \\
\text { N } \\
\text { Cox \& Snell R Square } \\
\text { Nagelkerke R Square }\end{array}$ & \multicolumn{3}{|c|}{$\begin{array}{l}1048.000 \\
539.223(22) \\
0.001 \\
1447 \\
31.1 \\
46.7 \\
\end{array}$} \\
\hline
\end{tabular}


The gross differentials in respondents' choice of medical and health facility, by and large, would be inconclusive and findings drawn from such analysis have their own limitations.

Hence, an attempt is made to identify the major factors that are likely to determine the respondents' choice of health facility. For this purpose, the respondents' choice of medical and health facility been considered as dependent variable, which has been measured as dichotomous viz., whether the respondent chosen to visit private health facility (by assigning a score of ' 1 ') or government health facility (score of ' 0 ') and explanatory variables as categories. In this case, use of logistic regression analysis is more appropriate and therefore, such an analysis is carried out.

The gross differentials in respondents' choice of medical and health facility, by and large, would be inconclusive and findings drawn from such analysis have their own limitations. Hence, in this section, an attempt is made to identify the major factors that are likely to determine the respondents' choice of health facility. For this purpose, the respondents' choice of medical and health facility been considered as dependent variable, which has been measured as dichotomous viz., whether the respondent chosen to visit private health facility (by assigning a score of ' 1 ') or government health facility (score of ' 0 ') and explanatory variables as categories. In this case, use of logistic regression analysis is more appropriate and therefore, such an analysis is carried out.

Among the sample workers, it is striking to note that, controlling for all the variables used in the model, the odds of their choice of availing medical and health care services from private centers are more than 11 times and 8.5 times higher (OR $=11.435$ and 8.523, respectively) among those who belonged to backward \& forward communities and most backward communities, respectively as against to those who belonged to Scheduled Castes / Tribes (lower in socio-economic strata). These results are also turn out as highly significant $(p<0.001$ in each case). These results are obvious because of the better socio-economic status among the workers belonged to former two communities as against to those form the latter category of communities. Another pertinent finding noticed here is that the role of quality of services existing in the health centres on workers' choice of health care services. Workers who ever perceived and availed the quality of services to an 'excellent' and 'good' extent have shown a greater tendency to choose private health care institutions during their illness to a large extent than their counterparts who felt such services are 'poor'. These results also found to be statistically highly significant ( $p<0.001$ in each case). Though such positive net effect is noticed in the case of those who stated that the quality of services at health centres at an 'average' level, the finding did not turn out statistically significant.

The likelihood of availing health care services from private health facilities is significantly higher among those workers who stated that it is used to take 15 and 10 minutes time for consultation with the doctor than those who reported such time as just five minutes $(p<0.001$ and $p<0.01$, respectively). Likewise, the probability of visiting to private medical and health care centers is appears to be higher among those workers who earn a monthly personal income of Rs. 3001-6000 as compared to those who earn comparatively lower income (Rs.3000 or less) and this finding is also turn out as highly significant $(p<0.01)$. However, it is surprising to note that such probability is negative among those workers who earn comparatively higher income. Another expected finding noticed in this analysis is that the positive net effect of educational status on workers' choice of health care services from private institutions. But the interesting fact noticed here is that though the odds of availing health care services from private health centres are noted to be higher in the case of all the levels of educational status of workers, the results turn out as statistically significant at a moderate level $(p<0.05)$ only in the case of those workers who are educated up to primary school level as compared to their illiterate counterparts.

Some of the factors have shown negative net effects on the workers' choice of health care services from private institutions. Among them the prominent one is waiting time at health facility to meet the doctor. It can be seen that the odds of visiting private health facilities are consistently lower among those workers in whose case the waiting time is more than 91 minutes or more, 61-90 minutes and 31-60 minutes as compared to those who spend less time (30 minutes or less) for such purpose. 
These results are turned out as statistically highly significant $(p<0.001$ in each case). This finding shows clearly that the workers, by and large, tend to avail the health care services to a quicker extent rather than waiting for a longer time. As noted in the case of bi-variate analysis, another pertinent finding observed here is that the likelihood of availing health care services by workers from private health facility is significantly $(p<0.001)$ lower if a government health centre is available nearer to their household than those do not have such facility. Likewise, the probability of visiting private health facilities for medical and health care services is much lower and significant $(p<0.001)$ among those workers who used to have a family doctor than those who do not have such a doctor. The net effects of other three variables under consideration viz., gender, current age and nativity status on the choice of workers' health care services though mostly on the expected direction, the results turn out as insignificant. Of course, such pattern is also true with regard to the first two factors in the case of bivariate analysis.

\section{CONCLUSION}

Giving importance to the quality of services, patients consider various factors in the selection of hospital such as the availability of the competent specialists, reputation of the hospital, professional management, range of services offered, availability of latest technology and equipment, cost and convenience, proximity to home, courteous behaviour of staff and professionalized care. Consumer research has shown that patients have several alternatives available to them in the selection of hospital. Number of studies has shown that patients consider good patient care as a very important factor in the selection of hospital, which consists of specialists, wide range and quality of services, best technology and equipment and the overall reputation of the hospital. It was found in a number of studies that, though the patients are very much interested in cost and convenience, they do not always consider cost as the most important factor in selecting a hospital. It is interesting to note that when it comes to health, patients are psychologically ready to pay any amount. They never tend to be treated in low cost hospitals but prefer a hospital where good treatment and quality services are available. Studies have shown that personalized care given by courteous and dedicated staff is also considered as an important factor by the patients in their list of priorities. It is the confidence in the competence of the doctor, which is closely followed by the quality of service provided and the reputation of the hospital that is attracting more numbers of patients in the present days.

The common diseases affecting the people in the study area are Dysentery / Diarrhoea, Gastroenteritis, Typhoid Fever, Chicken Pox, Diseases of Eyes, Food Poisoning, Accident \&Violence, Cold \& Cough, Skin Diseases and Other Unclassified Fever. Among the total sample of respondents a majority of them (48 per cent) stated that their overall health status is good. Only negligible amount (42 per cent) of sample workers reported that they had been suffering from chronic ailment like asthma, tuberculosis, ulcer and heart problem, diabetes, cancer and hypertension. While conducting the survey 394 respondents reported about their duration of illness. A majority of them (49 per cent) reported that they were sick only for 2 days and 27 per cent of them reported that they are sick during last one month. Among the total respondents only 13 per cent reported that they were hospitalized during last one year. A majority of 56 per cent said that they have visited the hospital once during the last month. Of the respondents who fell ill, a majority of them (43.4 per cent) have taken treatment from the private hospital and 29 per cent from private doctor together constitute 72 per cent. It is surprising to note that among the total respondents a majority of them ( 78.4 per cent) do not have a family doctor. It may be observed from the analysis that a majority of the workers (46 per cent) stated that distance of hospital from their residence is below $3 \mathrm{~km}$ and 36 per cent reported that the distance of pharmacy from their residence is $0-2 \mathrm{~km}$. On an average a majority ( 35.8 per cent) of workers stated that waiting time to meet the doctor is 30 minutes. An attempt has been made in the study to know the patients' views about the distance of the hospital from their residence. A majority of the workers (60.4 per cent) reported that they do not have medical facilities nearby home.

The gross differentials in respondents' choice of medical and health facility, by and large, would be inconclusive and findings drawn from such analysis have their own limitations. Hence, an attempt is made to identify the major factors that are likely to determine the respondents' choice of health 
facility. In this case logistic regression analysis is carried out. Among the sample workers, it is striking to note that, controlling for all the variables used in the model, the odds of their choice of availing medical and health care services from private centers are more than 11 times and 8.5 times higher $(\mathrm{OR}=11.435$ and 8.523 , respectively $)$ among those who belonged to backward \& forward communities and most backward communities, respectively as against to those who belonged to Scheduled Castes / Tribes (lower in socio-economic strata). These results are also turn out as highly significant $(p<0.001$ in each case). Another pertinent finding noticed here is that the role of quality of services existing in the health centres on workers' choice of health care services.

Workers who ever perceived and availed the quality of services to an 'excellent' and 'good' extent have shown a greater tendency to choose private health care institutions during their illness to a large extent than their counterparts who felt such services are 'poor'. These results also found to be statistically highly significant $(p<0.001$ in each case). Though such positive net effect is noticed in the case of those who stated that the quality of services at health centres at an 'average' level, the finding did not turn out statistically significant. The likelihood of availing health care services from private health facilities is significantly higher among those workers who stated that it is used to take 15 and 10 minutes time for consultation with the doctor than those who reported such time as just five minutes $(p<0.001$ and $p<0.01$, respectively). Likewise, the probability of visiting to private medical and health care centres is appears to be higher among those workers who earn a monthly personal income of Rs. 3001-6000 as compared to those who earn comparatively lower income (Rs. 3000 or less), and this finding is also turn out as highly significant $(p<0.01)$. However, it is surprising to note that such probability is negative among those workers who earn comparatively higher income. Another expected finding noticed in this analysis is that the positive net effect of educational status on workers' choice of health care services from private institutions. But the interesting fact noticed here is that though the odds of availing health care services from private health centres are noted to be higher in the case of all the levels of educational status of workers, the results turn out as statistically significant at a moderate level $(p<0.05)$ only in the case of those workers who are educated up to primary school level as compared to their illiterate counterparts.

A majority of the patients going to private hospitals select the hospital based on the performance of the doctors. This may be because many of the private hospitals are promoted by well-qualified and experienced doctors. These hospitals use the services of some of the best doctors in the state as well as in the country. These doctors are specialists and super specialists in specific health problems and have the expertise of using the most advanced technology and are exposed to the latest developments in medical and health care field through attending and participating in national and international workshops, seminars and conferences. Moreover, these doctors are generally referred to the patients by their friends, relatives and other doctors, especially in case of long-standing and complex health problems. When the researcher enquired about the reasons for choosing a particular health care system, around 26 per cent of the respondents stated that they select the health care system mainly for its timely attention.

An attempt is also made to analyse the differentials, if any, exist in workers' choice of health care services across their selected background characteristics. The analysis is carried out with the help of cross-tabulations and chi-square test of significance keeping the choice of health care services as dependent variable, viz., from government health facilities and private health centres. It is evident from the analysis that the percentage of workers who have availed health care services from private health centres is much higher irrespective their gender background, but this is just one percentage point is higher among males as compared to females, whereas such pattern is reversed in the case of government health facilities. When the differentials in the choice of health care services examined across their age, it is observed that the percentage of visiting private health facilities appear to be higher among those belonged to higher age groups ( $79 \%$ and $77 \%$, respectively among those whose age is 45 years \& above and 30-44 years) than those who are younger in age (15-29 years). Bivariate analysis in the case of choice of health care services by workers' marital status reveal that the percentage of those availing health care services from private health facilities is marginally higher 
among those who are currently married as against those who are in other type of marital status. The chi-square results in all the case of all these three factors did not turn out as statistically significant. It is obvious to note that workers who are born and brought up in urban areas have shown higher tendency to avail private health care services $(81 \%)$ than those workers whose nativity status is rural areas. Obviously, the reverse pattern is noticed among the sample workers in the case of government health services. Further, it is also interesting to note that the chi-square results between the nativity status and workers' choice of health care services is found to be highly significant $(p<0.001)$. From our analysis it is clear that quality of health care services is playing a vital role in choosing the type of health facilities by the workers. For instance, the percentage of the workers who utilise the private health care services is relatively lower $(57 \%)$ when they perceive and receive 'poor' health care services, which has increased consistently to 66.6 per cent, 77.7 per cent and then to as high as 90 per cent with an increase in the level of quality of services received at the health centers to the extent of 'average', 'good' and 'excellent', respectively. Conversely, the percentage of workers visiting government health facilities has decreased with an increase in the level of quality of health care services. Apparently, the chi-square results in this regard has turned out as highly significant indicating that there exists a strong association between the quality of health services and the choice of health care services $(p<0.001)$.

\section{ACKNOWLEDGEMENT}

I express my profound sense of gratitude to my research guide Dr. A. Sangamithra, Assistant Professor, Department of Economics, Bharathiar University for her valuable guidance, inspiration, meticulous supervision and constant encouragement for my full time Ph.D. research work. My special thanks go to Dr. M. John Sundar David, Professor and Dean, School of Social Sciences and Languages, VIT University, Vellore for his valuable suggestions and encouragement for my research and academic endeavour.

\section{REFERENCES}

- Canaviri (2007), "A Random Parameter Logit model for modeling Health Care Provider Choice in Bolivia", January.

- Felix Moneler M and Murugesan B (1990), "Rural Health Care Service-A Survey", Kurukshetra, Vol. XXXVIII, No. 4, pp. 35-41.

- Jawahar R and Kanagaraj E (2006), "Utilisation of urban Health Care in Tamil Nadu", National Seminar on "Health Sector Reforms", Annamalai University.

- Madhu Nagla (1989), Medical Sociology, Print Well Publishers, Jaipur, pp. 69.

- Madhu Nagla (1991), "Health Nutrition and Economic Development", Journal of Economic Literature, 36, pp: 766-817.

- Martin Valdivia M. (2002), "Public Health Infrastructure and Equity in the Utilization of Outpatient Health Care Services in Peru", Journal of Health Policy and Planning, 17(1): 12-19, CrossRef

- Rahman M, MM Islam, MR Islam, G.Sandhya and MA Latif (2011), "Disease Pattern and Health Seeking Behavior in Rural Bangladesh", Faridpur Medical College Journal, 2011; 5(1):32-37, CrossRef

- Ramanan Sunder (1992), "Household Survey of Medical Care", Margin, Vol.10, No.2, pp.169175.

- Ramanujam P.G. (2009), "Marketing of Healthcare Services", Excel Books, New Delhi.

- Sagaya Doss S (2008), "Economic Analysis of Health Care Services', Serials Publications New Delhi.

- Venkateswara Rao (1991), "Improving Rural Health Scenario", Kurukshetra, Vol. 20, No.4, pp. 36-38.

- World Bank (1998), World Resources 1998-99, Oxford University Press, New York.

- Yingchun Peng and et al. (2010), "Factors Associated with Health-Seeking Behavior among Migrant Workers in Beijing, China", BMC Health Services Research 2010, 10:69, CrossRef 